Journal of Environmental Assessment Policy and Management

Vol. 19, No. 3 (September 2017) 1750013 (20 pages)

(C) The Author(s)

DOI: $10.1142 / \mathrm{S} 1464333217500132$

\title{
Brownfields Remediation: Impact on Local Residential Property Tax Revenue
}

\author{
Karen A. Sullivan* \\ US Environmental Protection Agency \\ Office of Land and Emergency Management \\ Office of Communications, Partnerships and Analysis \\ 1200 Pennsylvania Avenue, N.W., MC 5101IT \\ Washington, DC 20460, USA \\ sullivan.karen@epa.gov \\ Received 30 December 2016 \\ Revised 1 February 2017 \\ Accepted 4 August 2017 \\ Published 13 September 2017
}

\begin{abstract}
The US Environmental Protection Agency (EPA) Brownfields Program provides grants to assess and clean up brownfields. There are few studies that estimate tax revenue impacts from cleanup beyond those generated directly from within the remediated site's property lines. This study estimates the increased residential property tax revenue attributable to brownfields cleanup at 48 sites remediated between 2004 and 2011 under the EPA Brownfields Cleanup Grants Program. Findings from a previous study of a 5\% to $15.2 \%$ property value increase following cleanup at these sites are applied to the assessed values of nearby residential properties along with local tax laws, assessment ratios, and rates to estimate tax revenue gained as a result of brownfields cleanup. The estimated increase in residential property tax revenue for a single tax year from remediating 48 brownfields properties was between \$29 million and \$97 million (2014 USD).
\end{abstract}

Keywords: Brownfields; contaminated land; property values; remediation; tax revenue.

\footnotetext{
*Disclaimer: The views expressed in this paper are those of the author and do not necessarily reflect the views or policies of the U.S. Environmental Protection Agency.

This is an Open Access article published by World Scientific Publishing Company. It is distributed under the terms of the Creative Commons Attribution 4.0 (CC-BY) License. Further distribution of this work is permitted, provided the original work is properly cited.
} 


\section{Introduction}

The US Environmental Protection Agency (EPA) Brownfields Program provides grants to assess and clean up brownfields. A brownfield is "a property, the expansion, redevelopment, or reuse of which may be complicated by the presence or potential presence of a hazardous substance, pollutant, or contaminant (US EPA 2017)." Cleaning up of land, whether for commercial, industrial, residential, recreational, greenspace or other productive use, may result in jobs to local residents, increased property values, or it may provide recreational or other services to make the community a better place to live. Land reuse can also affect the fiscal situation of local and state governments. In a survey conducted by the US Conference of Mayors in 2010, $85 \%$ of the 150 surveyed cities identified tax base growth as one of the four most important benefits that would accrue to their city if their brownfields were redeveloped (US Conference of Mayors, 2010). At a minimum, cleanup and redevelopment can increase local tax revenue by returning abandoned properties to the tax rolls. Additionally, if land cleanup and reuse result in higher values of nearby properties, brownfields redevelopment can further increase the local property tax revenues. Also, changes in the number of new businesses, employment rates and incremental consumer spending can affect state income tax and local and state sales tax revenue (US Environmental Protection Agency, 2011). Increased tax revenues provide a larger pool of funds for municipalities to provide public services and education to local communities.

Potential additional tax revenue from brownfields cleanup and redevelopment may also be an important factor for local, state or federal government officials deciding whether to invest in cleanup and redevelopment. Brownfields cleanup and redevelopment are usually accomplished through a combination of public- and private-sector funding. In a typical public-private partnership associated with brownfields, a public entity will sponsor the project and provide some initial funding, often for assessments to remove contamination uncertainties and for infrastructure to support development. A private-sector developer then funds and manages the pre-development and construction process. The initial public investment provides the necessary incentives for private sector development and operations. These partnerships reduce financial burden on the public sector while accelerating property cleanup, redevelopment and community revitalisation. Additional tax revenues generated from brownfields cleanups can be used to support the initial public funding. Public funding sources may include local, state 
or federal government programs that offer tax credits, tax abatements, tax increment financing (TIF), grants, subsidies, bonds or loans. ${ }^{1}$

There are many case studies that estimate the additional tax revenue expected or realised from adding a single brownfield property back onto the tax roll; however, there are few studies that look beyond a site's property lines to estimate the additional property tax revenue that may accrue from increases in nearby property values occurring as a result of the cleanup. For example, a case study reports that a closed tire service shop that left behind waste oils and hydraulic fluids in Frisco, Colorado was remediated and put to reuse as Uptown Bistro Restaurant, which generates $\$ 57,000$ in property and sales tax revenue annually (Colorado Department of Public Health and Environment, 2005). Another study of 17 brownfields across the US reports that the additional annual property tax revenue from putting those remediated brownfields back onto the tax roll ranged from $\$ 20,534$ at the Merchandise Mart Project in Louis, MO to \$20.4 million at the Compuware Headquarters in Detroit, MI (Redevelopment Economics, 2015). The tax revenue identified in these case studies includes only those generated directly from the remediated property, and therefore; only shows a portion of the additional tax revenue that may accrue to local governments and do not account for the broader impact of cleanup on tax revenue from nearby properties. To date, only a few geographically narrow studies have estimated additional tax revenues accruing from beyond the property line as the result of cleanup of the contaminated site. ${ }^{2}$ For example, Chattopadhyay et al. (2005) estimated that the present value of the projected increase in residential property tax revenue from properties nearby to the Waukegan Harbour, a Superfund site on the Great Lakes, ranges from $\$ 10.25$ million to \$16.02 million, and Mihaescu and Vom Hofe (2013) estimated that based on depressed values of properties located within 2,000 feet of 87 brownfields in the City of Cincinnati, the city loses $\$ 2,262,569$ in annual tax revenue, which presumably could be recovered if those brownfields were remediated.

\footnotetext{
${ }^{1}$ TIF is a method of facilitating development or redevelopment of an area by earmarking future property tax revenues that are realised from taxes generated only from the TIF District to pay for the public improvements.

${ }^{2}$ There are studies in other contexts that estimate the impacts of land use on property tax revenues (e.g., preserved agricultural land in three Maryland counties (Geoghegan et al., 2003), green space in downtown Los Angeles (Conway et al., 2010), open space in New Jersey (Vandegrift and Lahr, 2008), a shopping center in Tennessee (Yu et al., 2012), conservation easements in Vermont (King and Anderson, 2004), etc.).
} 


\section{K. A. Sullivan}

Given the importance of tax revenues for local municipalities to provide goods and services to the local community and that a frequently identified barrier to brownfields redevelopment is a lack of cleanup funding, ${ }^{3}$ it is surprising that little attention has been paid to measuring the benefits that brownfields cleanup and redevelopment provide to local governments beyond taxes and jobs generated from the project site itself (De Sousa et al., 2009). This study addresses this knowledge gap by estimating the increased residential property tax revenue attributable to brownfields cleanup at 48 sites that were remediated between 2004 and 2011 under the EPA Brownfields Cleanup Grants Program. This study utilises the findings of a previous analysis by Haninger et al. (2017) (hereafter HMT), who use a hedonic approach combined with a variety of quasi-experimental techniques to estimate the impact of brownfields remediation on nearby housing property values. HMT (2017) find evidence of increases in housing property values accompanying brownfields cleanup, ranging from $5 \%$ to $15.2 \%$ for residential properties within $2.07 \mathrm{~km}$ of the site. This study applies this range of property value increases to the assessed values of nearby residential properties to estimate the increase in the residential property tax base attributable to brownfields cleanup. Local tax laws, assessment ratios, and rates are then used to estimate the tax revenue gained from the estimated additional tax base. The estimated increase in residential property tax revenue for a single tax year from remediating 48 brownfields properties was between $\$ 29$ million and $\$ 97$ million - an average of $\$ 606,046$ and $\$ 2,018,854$ per site (2014 USD). Realisation of this additional tax revenue is expected to occur when residential properties are reassessed after cleanup. Note that this estimate neither includes additional tax revenues from the brownfields property itself nor from nearby commercial properties that may be generated as a result of the cleanup.

\section{The US EPA Brownfields Program}

The US EPA Brownfields Program is designed to empower states, communities and other stakeholders to work together in a timely manner to prevent, assess, safely clean up, and sustainably reuse contaminated or formerly contaminated land. ${ }^{4}$ Brownfields grants serve as the foundation of the Brownfields Program and

\footnotetext{
${ }^{3}$ In a survey conducted by the US Conference of Mayors in 2010, $84 \%$ of the 150 surveyed cities identified that the most frequent impediment they encounter in redeveloping brownfields sites was lack of cleanup funds (US Conference of Mayors, 2010). Other barriers include the need for environmental assessments to be conducted, poor market conditions, and liability issues.

${ }^{4}$ http://epa.gov/brownfields/. See the EPA webpage for further details on the Brownfields Program and a link to public law 107-118 (H.R. 2869), "Small Business Liability Relief and Brownfields Revitalization Act."
} 
support land revitalisation efforts by funding environmental site assessment, cleanup, and job training activities. Since the passage of the Small Business Liability Relief and Brownfields Revitalization Act of 2002 (the "Brownfields Law"), EPA has competitively awarded 2,790 assessment grants totalling \$664.3 million, 344 grants to capitalise revolving loan funds totalling $\$ 331.4$ million, and 1,187 cleanup grants totalling $\$ 226$ million (inclusive of FY 2016). In addition to the US EPA's Program, nearly every state has established its own brownfield or voluntary cleanup program, which is often accompanied by grant and loan support (Wernstedt, 2010).

The typical US EPA cleanup grant is awarded for $\$ 200,000$ but the amount may vary depending on the particular needs at the site. The remainder of cleanup and redevelopment costs are incurred by other federal agencies, state and local government, or the private sector. Potential additional tax revenue may be an important factor for local or regional officials deciding whether to invest in cleanup and reuse efforts and during the consideration of cleanup financing options.

\section{Residential Property Taxes in the US}

Local governments levy taxes on real properties, which include residential homes, commercial properties, and land. Property taxes are a major source of revenue for local governments in the US, and are an important funding source for the provision of local amenities and services (Barnett and Vidal, 2013). Property owners' tax obligations vary across states as a result of the wide variation in state tax laws and states' dependence on property tax revenues (Harris and Moore, 2013). ${ }^{5}$ Local property tax revenue is determined by the local tax rate and tax base. The tax base is determined by the total assessed value of property in a municipality and an assessment ratio, which is the share of the assessed value that is subject to taxation.

Assessors determine the assessed values of properties based on either the value of the property when it was acquired or more commonly on the fair market value of the property (Harris and Moore, 2013). ${ }^{6}$ The property tax base is typically set by the full fair market value (e.g., New York's property taxes are calculated at $100 \%$ of the market value) or by some fraction of the fair market value (e.g., Ohio's property taxes are based on $35 \%$ of the market value). States also have a variety of

\footnotetext{
5 This section summarises Harris and Moore's (2013) overview of property taxes in the US. For a more comprehensive review of this topic refer to their report, "Residential Property, Taxes in the US".

${ }^{6}$ The comparable sales approach in which the appraiser compares a property to other recently sold properties with similar characteristics is the most common method for determining an assessed value on the fair market value.
} 


\section{K. A. Sullivan}

laws to limit property taxes such as homestead exemptions that lower property taxes for owner-occupied housing, "circuit breakers" that reduce the level of tax for certain types of owners (e.g., senior citizens or low-income households) and abatements that eliminate taxes for certain taxpayers (e.g., senior citizens or veterans) (Harris and Moore, 2013). As the impact of brownfields cleanups on residential property, tax revenue is estimated, it is important that the assessment ratio, tax rates, and tax limiting laws in each brownfields site's particular location are accounted for.

\section{Measuring Property Value Impacts of Land Remediation}

Property value data can be used in a variety of ways to estimate the effects of a change in an environmental amenity or disamenity. In the land cleanup literature, the hedonic approach is the most commonly used method. ${ }^{7}$ The hedonic pricing method has its theoretical foundation in Rosen (1974) and is commonly used to estimate the marginal willingness to pay for a non-market housing amenity. ${ }^{8}$ This method is based on the idea that homeowner's utility or disutility from living close to an amenity or disamenity can be measured by observing compensating price differentials in housing markets. In the context of Superfund National Priorities List cleanups, there are several widely-cited papers that have used the hedonic approach (Michaels and Smith, 1990; Kiel, 1995; Ihlanfeldt and Taylor, 2004; Kiel and Williams, 2007; Greenstone and Gallagher, 2008; Gamper-Rabindran and Timmins, 2013), but there are fewer well-known hedonic studies in the context of brownfields. 9 This is largely due to the relative youngness of the Brownfields Program. The Brownfields Program began with the passage of the Small Business Liability Relief and Brownfields Revitalization Act of 2002 whereas the Superfund Program began over three decades ago with the Comprehensive Environmental Response, Compensation and Liability Act of 1980.

In the context of brownfields cleanups, a few studies have used property values to estimate the depression in property prices attributable to the disamenity of a nearby unremediated brownfield (Kaufman and Cloutier, 2006; Mihaescu and vom Hofe, 2012, 2013; Schwarz et al., 2016). Some of these studies then use the

\footnotetext{
${ }^{7}$ For a more comprehensive discussion of the various methods that can be used to estimate the effect of land cleanup and reuse on property values, refer to the US EPA's National Center for Environmental Economics' Handbook on the Benefits, Costs, and Impacts of Land Cleanup and Reuse (US Environmental Protection Agency, 2011).

${ }^{8}$ See Taylor (2003) and Palmquist (2005) for a discussion of the hedonics method.

${ }^{9}$ For a review of these and other hedonic studies of land contamination and cleanup, see Jenkins et al. (2006).
} 
depression in property prices as an estimate of the property value that could be gained if the brownfield was cleaned up (Kaufman and Cloutier, 2006; Mihaescu and vom Hofe, 2013). Additionally, a few studies have examined the impact of brownfields cleanup and redevelopment using property values from before and after the cleanup (Corona, 2004; De Sousa et al., 2009; Schwarz et al., 2016; Haninger et al., 2017). For example, De Sousa et al. (2009) examined 103 brownfields in Minneapolis, Minnesota and Schwarz et al. (2016) examined brownfields in Charlotte, North Carolina. Both of these studies find evidence that brownfields cleanup and redevelopment had a positive effect on nearby property values. However, Schwarz et al. (2016) found an increase in price due to brownfields cleanup for homes between 0.5 miles and 2 miles, but a decrease for homes within 0.3 miles, which they speculate to be the result of a nearby visual disamenity that remains after remediation.

To date, in the context of brownfields cleanups, the most empirically robust and geographically dispersed study that estimates the effects of brownfields cleanup on nearby property values is the recent study by HMT (2017). When implementing the hedonics method, a bias may arise if there are housing or neighbourhood attributes that are unobserved by the researcher and correlated with the attribute of interest. Brownfields Cleanup Grants are competitively awarded, and as a result, the locations of brownfields that are awarded cleanup grants may systematically differ from locations of those that are not awarded grants. If these unobservable attributes are not properly accounted for, the estimated impacts of cleanup on property values may be biased. A variety of statistical approaches has been developed to address this problem including quasi-experimental and other approaches such as fixed effects, difference in differences, instrumental variables and matching estimators. ${ }^{10}$ HMT (2017) utilised the hedonic pricing method coupled with several approaches including fixed effects, difference in differences, and nearest neighbour matching to overcome the presence of correlated unobservable determinants of housing prices both time-invariant and those that vary over time.

HMT (2017) begin with a simple cross-sectional estimation that compares house transaction prices within $5 \mathrm{~km}$ of brownfields after cleanup versus brownfields that have not yet been cleaned up while controlling for house attributes, brownfields attributes, and the transaction year. The cross-sectional estimation produces counterintuitive results - that cleanup has a negative impact on nearby property values. The authors indicate that this result may suffer from an omitted

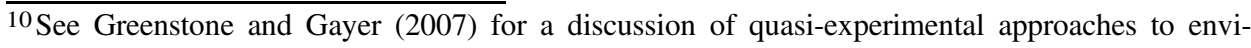
ronmental economics.
} 


\section{K. A. Sullivan}

variable bias if cleanup grants are targeted towards the struggling neighbourhoods and those neighbourhood attributes are correlated with cleanup status. To address this potential bias caused by time-invariant unobservable neighbourhood attributes, HMT (2017) utilise fixed effect specifications at the brownfields site or house level. The fixed effect specifications compare house prices sold before and after cleanup, and find statistically significant increases in house prices from cleanup ranging between $8 \%$ and $11 \%$.

While the fixed effect specifications are able to deal with time-invariant unobservable neighbourhood attributes, the results may be biased if there are time-varying unobservables that are correlated with brownfields cleanup. HMT (2017) implement difference in differences specifications to address the possible presence of time-varying unobservables. In the difference in differences estimations, HMT (2017) compare the changes in house prices before cleanup and after cleanup among houses near to a brownfield (treatment group) to those houses farther away from the brownfield (control group). More specifically, they compare prices before cleanup and after cleanup of homes within $2.07 \mathrm{~km}$ of a brownfield to those that are between $2.07 \mathrm{~km}$ and $5 \mathrm{~km}$ away, while also controlling for attributes of the home and the brownfield. ${ }^{11}$ Results from the difference in differences estimates suggest increases in property values of between $5 \%$ and $7 \%$.

A limitation of the fixed effects and difference in differences estimators are that both rely on the assumption that the hedonic price function remains stable over time. This assumption may not hold if cleanup leads to neighbourhood turnover and changes in marginal willingness to pay for cleanup, which is suggested by recent research (Banzhaf and McCormick, 2007; Wolverton, 2009). This motivates HMT (2017) to specify a double-difference matching nearest neighbour estimation that does not rely on stability of the hedonic price function overtime. In this last specification, HMT (2017) exploit variation in data across treated houses around cleaned and uncleaned brownfields to estimate a separate hedonic price function for each year. The estimation process has two stages. In the first stage, a nearest neighbour matching algorithm is used to pair houses within a $2.07 \mathrm{~km}$ buffer of a brownfield after cleanup with similar houses that are near to a brownfield that has not yet been cleaned up. These matches are used to identify the individual treatment effects, and are saved for the second stage. The process is

\footnotetext{
${ }^{11}$ HMT (2017) estimate a pair of price functions over distance from the nearest brownfield site to identify at what distance the pre-cleanup and post-cleanup price functions converge (i.e., the distance at which cleanup no longer affects house price). They find that prices on average are higher after cleanup at all distances, but the difference is no longer statistically significant outside of $2.07 \mathrm{~km}$, and therefore define the treatment group using a $2.07 \mathrm{~km}$ buffer. See HMT (2017: 215-219) for more details.
} 
repeated for those houses outside the treatment buffer $(2.07 \mathrm{~km}$ to $5 \mathrm{~km})$ of a remediated and not yet remediated brownfields. In the second stage, HMT (2017) recover an estimate of the average treatment effect for each year by differencing the average estimates from the first stage of the treatment group (within $2.07 \mathrm{~km}$ ) and the control group $(2.07 \mathrm{~km}$ to $5 \mathrm{~km})$. The double-difference matching nearest neighbour specification identifies even larger effects of cleanup on house prices of up to $15.2 \% .^{12}$ HMT's (2017) fixed effects and quasi-experimental approaches together yield a consistent conclusion - "averaging over the experiences at a nationally representative sample of brownfields properties, cleanup leads to housing price increases between $5.0 \%$ and $15.2 \%$."

\section{Methodology}

This analysis utilises the property value increases identified in HMT (2017) to estimate the additional residential property tax revenue resulting from cleanup for a subset of sites originally included in the HMT (2017) analysis. The subset of sites was determined by both the availability of tax assessment property value data and the applicability of this methodology in the location of each brownfield. Estimating the additional residential property tax revenue resulting from brownfields cleanup requires three steps: (1) estimate the pre-cleanup residential tax base within a $2.07 \mathrm{~km}$ circular buffer of each brownfield, (2) apply the estimated property value increases of $5 \%$ and $15.2 \%$ resulting from brownfields cleanup to the pre-cleanup tax base, and (3) apply local tax assessment ratios, laws and rates to the estimated additional residential property tax base. Each of these steps is explained in detail below.

\section{Estimating the pre-cleanup residential property tax base}

To estimate the additional residential property tax revenue resulting from brownfields cleanup, first the tax assessed value prior to cleanup for all residential properties within a $2.07 \mathrm{~km}$ circular buffer of each site's latitude and longitude coordinate was identified. For consistency, this analysis includes only those residential property types that were included in HMT (2017) - single family dwelling, multifamily dwelling (up to four units), mobile home, and individually owned condominium unit. Assessed values for a tax year prior to the start of cleanup is used to establish the nearby residential tax base before cleanup. The exact data year depended on the availability of tax assessment data at the local tax

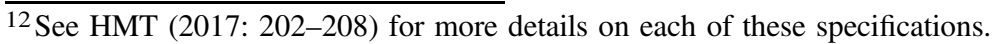




\section{K. A. Sullivan}

office and was typically the assessed value from one to two years prior to the cleanup start date. All values have been normalised to 2014 USD using the annual, regional All Urban Consumers Housing Consumer Pricing Index from the Bureau of Labour Statistics. Once all the residential properties within $2.07 \mathrm{~km}$ of the brownfields sites were identified, their assessed values were summed to calculate the total pre-cleanup residential property tax base within the $2.07 \mathrm{~km}$ buffers.

\section{Estimating the additional residential property tax base after cleanup}

Next, the estimated increase in the residential tax base attributable to remediation at each brownfield was calculated based on HMT's (2017) findings that the value of residential properties nearby brownfields increase between $5 \%$ and $15.2 \%$ after cleanup. HMT's (2017) findings are based on home sale prices, but here they are applied to tax assessed values of homes. ${ }^{13}$ Housing market sale transaction data are not used here because to calculate the total value of residential properties prior to cleanup within the $2.07 \mathrm{~km}$ buffer, the value of every home within the buffer must be known, and housing market sales transaction would only provide a value for those homes that sold in a given year. The appropriateness of applying findings from a study based on market price data to assessed values depends on the degree to which changes in the assessed values correlate with changes in the market values of properties with similar attributes in the study locations. This is a reasonable assumption because assessed values are typically based on the fair market value of a property, and the assessments are often evaluated by local and state agencies using ratio studies to ensure that properties are uniformly assessed based on market values.

\section{Estimating the additional residential property tax revenue after cleanup}

In the last step, each location's assessment ratio, which is the share of the assessed value that is taxed, is used to determine the portion of the tax base to which the tax rate should be applied. Then, the local tax rate from the same year as the assessed value data is used to estimate the additional tax revenue that is attributable to each cleanup. Tax policies enacted by state lawmakers that lower property taxes for owner-occupied housing — often referred to as homestead exemptions — are also

\footnotetext{
${ }^{13}$ Assessed values are determined by tax assessment officers who estimate the assessed value based on legal requirements and accepted appraisal definitions and methods whereas market prices recorded in sales transaction data are determined by market forces (i.e., housing market demand and supply).
} 
factored into the estimation. If a property is located in a state with a homestead exemption, the appropriate reduction is factored into the calculation of the additional tax revenue. These exemptions are incorporated in two different ways depending on the information available for the residential tax parcels. If the data include information on the owner-occupancy status of a property, then that information is used to determine if the property is eligible for a tax reduction. If there is no owner-occupancy status information in the parcel data, then data from the 2000 US Census is used to identify the percentage of properties in the county that are owner-occupied and the tax reduction is then applied to that percentage of the residential properties (US Census Bureau, 2000). Other tax limiting laws such as "circuit breakers" that reduce the tax burden on a particular group of taxpayers (e.g., low income, seniors or veterans) are not considered in the estimates due to the inability to determine which parcels qualify for the reductions from the tax assessment data. As a result, the estimated additional tax revenue identified may be slightly overestimated and the size of which would depend on the extent that these tax limiting laws exist and home owners qualify and apply for the tax breaks.

\section{Limited ability to apply methodology in some states}

The methodology described above is appropriate for brownfields located in states where properties are reassessed for tax purposes on a regular basis, typically every 2-5 years, as well as in states that do not have a "tax cap" or other laws in place that limit the amount a tax bill can legally increase each year. Due to unique state tax laws, brownfields that were located in California, Florida, Nevada, Oklahoma, Oregon, or Texas were excluded from this analysis. For example, in California, as a result of Proposition 13, a residential property is only reassessed for tax purposes when it changes ownership. Since California does not reassess all of its properties on a regular basis, it would take many years for the estimated additional tax revenue attributable to brownfields cleanup to be fully realised (i.e., all properties would need to change ownership). In Nevada, the Assembly Bill 489 applies a 3\% cap on the tax bill of an owner's primary residence unless the property has had new construction or a change in use (Washoe County Assessor, 2013). Special tax laws like these make it inappropriate to estimate the impact that the increased property value attributable to brownfields cleanups would have on tax revenues using the methodology as described above in some states. As a result of this issue, 32 of the 115 brownfields included in HMT's (2017) study were excluded from this analysis. 


\section{Data}

Every effort was made to obtain the data necessary to identify the assessed value of all residential properties near the 83 brownfields from HMT (2017) to which the methodology could be applied, however; for 35 brownfields, sufficient data were not available. First, tax parcel maps for the municipalities that each brownfield site's buffer fell into were located, and then were used to identify the parcels that fell within each brownfields site's $2.07 \mathrm{~km}$ circular buffer. This was done in a variety of ways, depending on the format of the tax parcel maps held by local tax assessor's offices and planning commission offices as well as the offices' ability to share the information. In most locations, it was possible to obtain GIS parcel map data for the entire town and to use ArcGIS 13.0 software to identify those parcels that fell within the buffer. ${ }^{14}$ For some locations, the local tax or planning office chose to identify those residential parcels within the buffers themselves and to provide us with the resulting parcel list. Additionally, there was one location for which hard copy parcel maps were used to draw the buffer by hand and manually identify and record each parcel that fell within the buffer. Once all residential parcels within the buffer of the site were identified, the next step was to obtain the assessed value data from each local tax assessment office for a year prior to the cleanup start date. The assessment data years retrieved ranged from 2002 to 2008 . In the end, assessed values were identified for the residential properties within $2.07 \mathrm{~km}$ of 48 brownfields across 17 states, including Colorado, Connecticut, Indiana, Iowa, Massachusetts, Michigan, Minnesota, Missouri, North Carolina, New Hampshire, New Jersey, New York, Ohio, Rhode Island, South Carolina, Washington and Wisconsin.

\section{Results}

\section{Impacts on property tax revenues}

Table 1 summarises the results of each step taken to estimate the impact of brownfield cleanup on residential property tax revenue. Within the $2.07 \mathrm{~km}$ circular buffer of the 48 brownfields, there were 219,732 residential properties with a total assessed value prior to cleanup of \$39.4 billion (2014 USD). Applying

\footnotetext{
${ }^{14}$ Historical parcel maps that matched the desired year of assessed property value data in each location were initially sought; however, in almost all locations, only current (or fairly recent) parcel maps were available. I believe that using current parcel maps rather than historical parcel maps to identify the parcels within the buffer could only have a very minor impact on the estimates because in most locations, the historical assessed value data allowed us to determine if the parcel existed and its property use type in the historical year.
} 


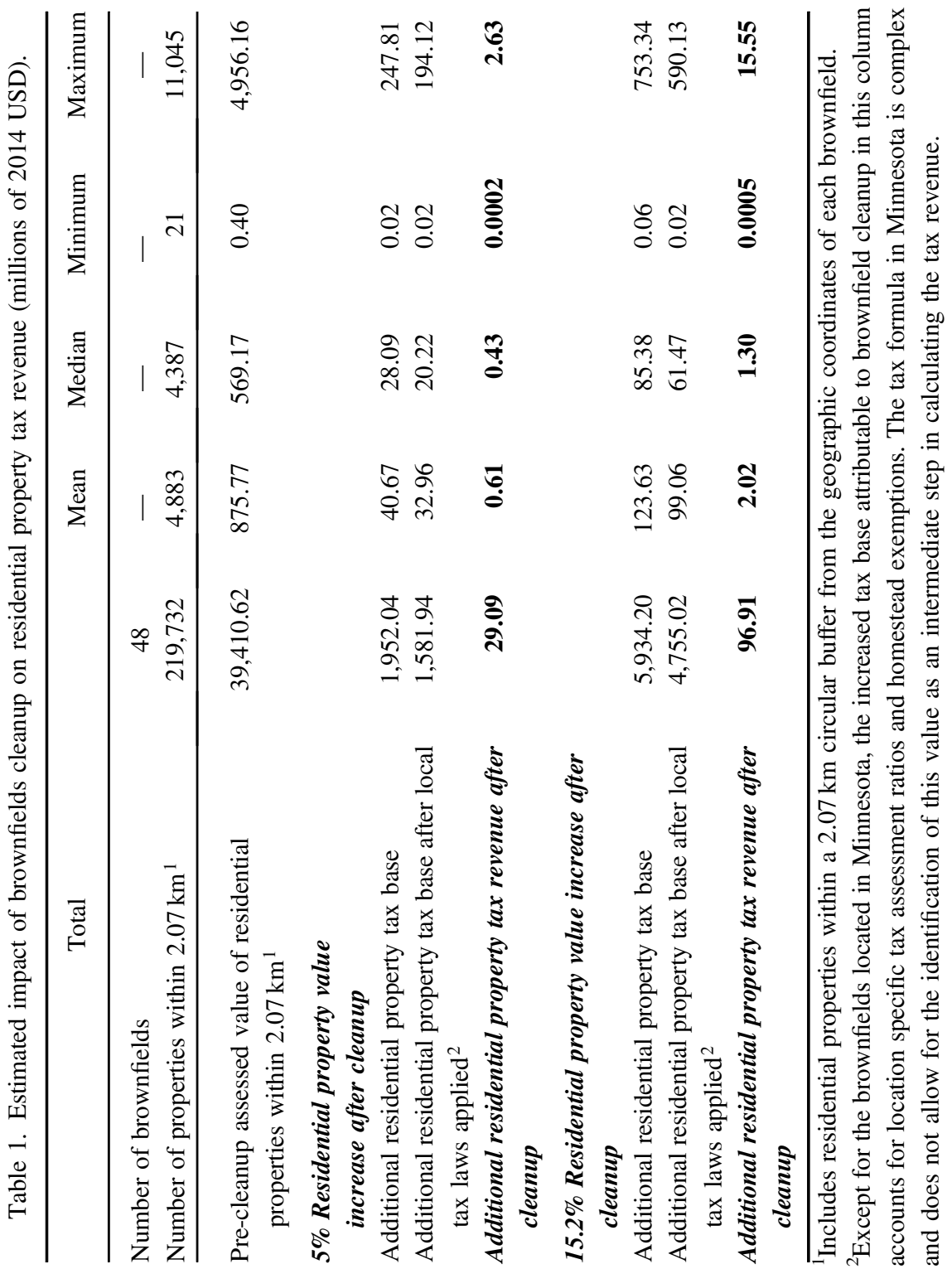




\section{K. A. Sullivan}

the property value increases identified in HMT (2017) of 5\% to $15.2 \%$ to the total residential property tax base within the buffers results in an additional $\$ 1.95$ billion to $\$ 5.93$ billion in residential property tax base. After taking into account the tax assessment ratio and homestead exemptions, the total additional residential property tax base attributable to the cleanup was reduced to between $\$ 1.58$ billion and $\$ 4.75$ billion. The local tax rates were applied to this additional tax base, resulting in a total estimated single year increase in residential property tax revenue between $\$ 29.1$ million and $\$ 96.9$ million from the remediation of these 48 brownfields. Realisation of this additional tax revenue is expected to occur when residential properties are reassessed for tax purposes after cleanup. It is reasonable to assume that this increase in tax revenue attributable to cleanup would persist into the future, however; caution should be taken to extrapolate too far into the future as findings from HMT (2017) applied here are short run effects of brownfields cleanup on property values. ${ }^{15}$ In the long run, there may be feedback effects that could impact the estimated impact of brownfields cleanup on property values. As more post-cleanup sales transaction data become available, future research should examine the long run impact of brownfields cleanup on property values.

While the average estimated annual increase in residential property tax revenue at a single brownfields cleanup associated with property value increases of between $5 \%$ and $15.2 \%$ was $\$ 606,046$ and $\$ 2,018,854$, respectively, there was significant variation in the estimated increase in tax revenue from cleanup at individual brownfields. For example, with a $5 \%$ property value increase from nearby cleanup, the estimated range of additional tax revenue at a single site was between $\$ 167$ and $\$ 2,628,170$. The variation across sites and states is due to differences in the number and value of residential properties surrounding the brownfields as well as the state and local tax assessment ratios, tax rates and tax laws.

Table 2 summarises the results grouping brownfields by the state each is located in and illustrates those factors that impact the potential additional tax revenue. For example, based on an estimated property value increase of 5\% from brownfields cleanup, the mean residential property tax revenue increase at the 11 brownfields located in Massachusetts is $\$ 839,073$, while it is only $\$ 211,787$ at the 3 brownfields in South Carolina (Table 2, rows 5 and 15). This difference in estimated additional residential tax revenue is driven by a higher mean home value in Massachusetts than in South Carolina and differing tax laws and rates across the two states. At the 11 brownfields in Massachusetts, the average number of residential

15 HMT (2017) analysis used sales transaction data from 1998 to 2012, and cleanups were completed at these 48 brownfields between 2004 and 2011 . 


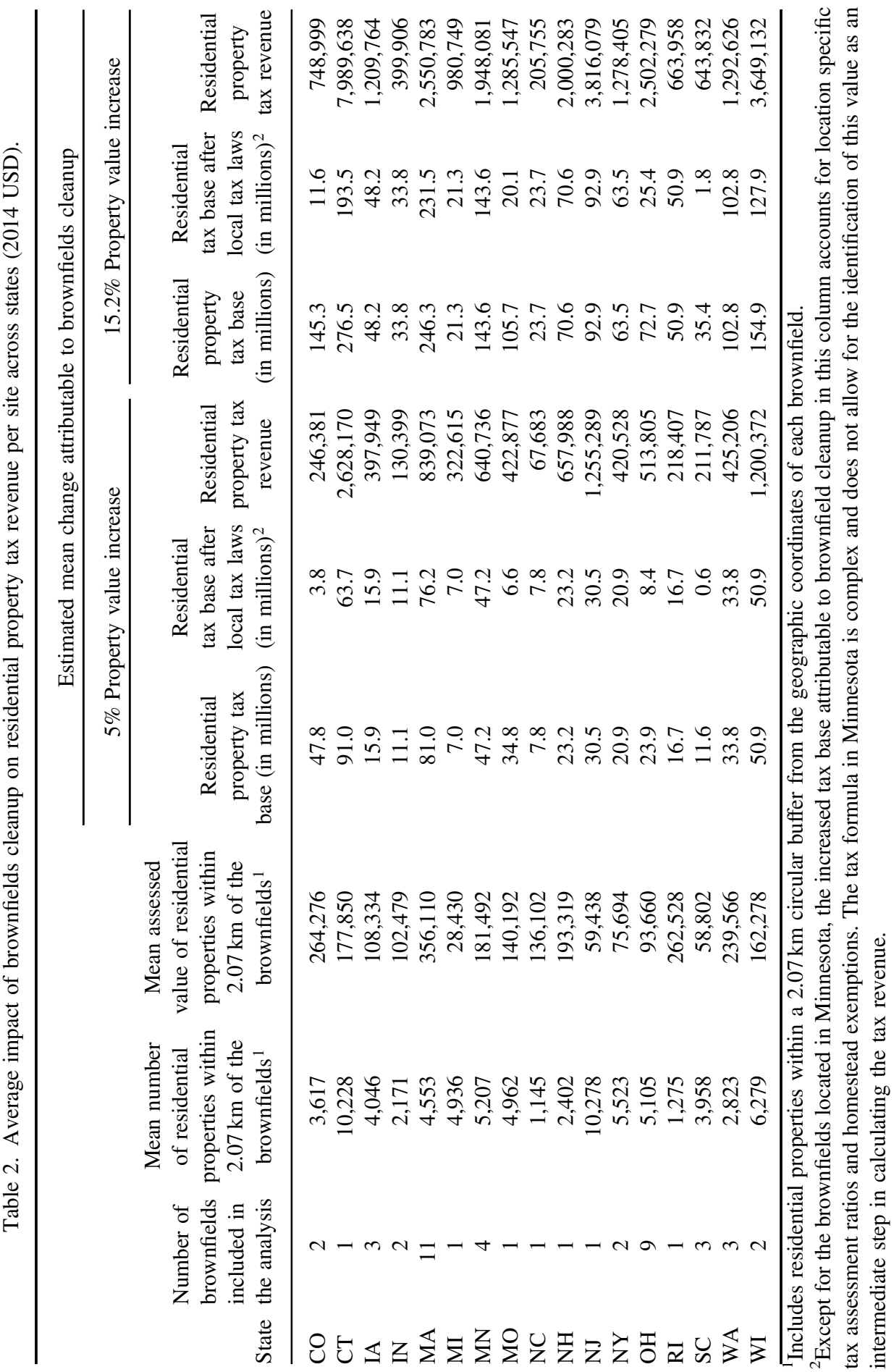




\section{K. A. Sullivan}

properties within $2.07 \mathrm{~km}$ of a site was 4,553 residential properties with an assessed average value of $\$ 356,110$, while at the 3 brownfields in South Carolina, the average number of residential properties was similar at 3,958 properties, but the average assessed value was much lower at only $\$ 58,802$. In Massachusetts, there are few tax limiting laws (i.e., majority of residential properties are taxed at $100 \%$ of the fair market value), and so there is only a small difference (i.e., a $6 \%$ reduction) between the estimated additional residential tax base before and after the Massachusetts tax laws are applied (Table 2, columns 5 and 6). Whereas in South Carolina, only $4 \%$ or $6 \%$ of the assessed value is taxed depending on owner-occupancy status of the property. This results in a large difference (i.e., a 95\% reduction) after the local tax laws are applied. This example highlights that local governments or other stakeholders interested in estimating the additional residential property tax revenue that may accrue after a brownfield site is remediated must consider the nearby housing density and assessed values as well as the local tax laws and rates.

Note that the tax revenue increase estimated here does not consider the effect of exemptions other than the homestead exemption. Additional exemptions available to some property owners such as senior citizens or veterans may lower the amount of additional tax revenue that can be collected, but the information contained in the tax assessment data did not allow for consideration of these additional exemptions. Also, estimates include only the increased tax revenue from residential properties (including single family dwellings, mutlifamily dwellings with up to four units, mobile homes and individually owned condominium units) that existed prior to the cleanup of the brownfield. There may also be an increase in property tax revenue from other types of residential properties, such as multifamily dwellings with greater than four units or apartment buildings. Furthermore, if the brownfields cleanup and redevelopment attract businesses to the area, there may be increases in commercial property, sales or income tax revenues. As such, the estimated additional tax revenues from brownfields cleanup presented in this study are likely to be on the low end of the potential total impact of brownfields cleanup on tax revenues, but further research is needed to make any specific claims about the total impact of brownfields cleanup on local and state fiscal situations.

\section{Comparison of additional tax revenues to brownfields cleanup costs}

While a cost-benefit analysis of brownfields cleanup is beyond the scope of this analysis, a comparison of cleanup costs to the estimated additional tax revenue is provided for perspective on the value of brownfields cleanup. The EPA Brownfields Program provided a total of $\$ 12.4$ million (2014 USD) in cleanup grants to these 48 brownfields. After these 48 brownfields cleanups were completed and the surrounding residential properties were reassessed for tax purposes, using the 
conservative estimate from the property value increases found in HMT (2017) of $5 \%$, in just one year, the estimated additional residential property tax revenue accrued to local governments as a result of these cleanups (\$29.1 million) exceeds the amount EPA invested ( $\$ 12.4$ million). Note that EPA dollars invested are not the total cost of cleanup at these 48 brownfields. Additional costs of cleanup are often incurred by other federal agencies, the local government or private entities. While site-specific information on cleanup costs at these 48 brownfields is not available, the Northeast Midwest Institute has estimated that the average cost of a brownfield cleanup is $\$ 602,000$ (Paull, 2008). Using this estimate of cleanup cost, in just a single year, the estimated additional residential property tax revenue accrued to local governments as a result of these cleanups (\$29.1 million) slightly exceeds the estimated total cost of cleanup ( $\$ 28.8$ million). While this is an interesting comparison, the results should not be considered as a complete analysis of the cost and benefits the cleanup of these 48 brownfields because the cleanup costs are estimated and may not be accurate to these particular sites and the value of the full spectrum of benefits of brownfields cleanup has not been estimated. Also, the tax revenue impacts identified here are gross rather than net impacts. In other words, this study does not consider whether the tax revenues gained represent transfers from other areas within or outside the local municipalities' borders. This could occur if brownfield remediation affected property values beyond the immediate vicinity of the brownfield by affecting redevelopment patterns in the region.

\section{Conclusion}

Local, state and federal government officials have identified that brownfields cleanup and redevelopment are important for protecting human health and the environment and revitalising communities as well as for generating additional tax revenues, yet previously, few studies have quantified tax revenues beyond those generated from within the property lines of the remediated site itself. This study estimates that the increase in residential property tax revenue from the cleanup of 48 brownfields ranged from $\$ 29$ million to $\$ 97$ million in a single year after cleanup when nearby residential properties were reassessed, which is 2 to 7 times more than the amount EPA invested ( $\$ 12.4$ million). Also, the additional tax revenue generated from these 48 brownfields in just one year is greater than the estimated total cleanup cost ( $\$ 28.8$ million). This shows that it is critical for local, regional and federal government officials to consider all potential additional tax revenues that may be generated from brownfields cleanup and redevelopment when deciding whether to invest in cleanup and reuse efforts. Not only can these 


\section{K. A. Sullivan}

additional tax revenues be leveraged to fund public programs that incentivise cleanup and redevelopment such as tax credits, tax abatements, TIF, grants, subsidies, bond or loans, but also these additional tax revenues can be used by local governments to provide other public services to the local communities. Future research should take a broader perspective which captures additional tax revenues from other types of property near to the remediated brownfields (e.g., commercial or large apartment buildings) and that examines gains and losses in tax revenues across wider geographical areas.

\section{Acknowledgements}

Karen Sullivan conducted this analysis while supported by the AAAS Science and Technology Policy Fellowship Program and the US EPA. Data retrieval, entry and ArcGIS data work were supported by funding from the US EPA (contract GS-10F-0061N via Industrial Economics, Inc.), Bunmi Akinnusotu and Barbara Johnson (US EPA), Nicole Nakata (ASPPH Fellow at the US EPA) and local government and planning agency staff.

\section{References}

Banzhaf, H and E McCormick (2007). Moving beyond cleanup: Identifying the crucibles of environmental gentrification. National Center for Environmental Economics, Working Paper 07-02, US Environmental Protection Agency, Washington, DC.

Barnett, JL and PM Vidal (2013). State and Local Government Finances Summary: 2011. Governments Division Briefs. Washington, DC: United States Census Bureau. Available online: https://www.census.gov/prod/2013pubs/g11-alfin.pdf.

Chattopadhyay, S, JB Braden and A Patunru (2005). Benefits of hazardous waste cleanup: New evidence from survey-and market-based property value approaches. Contemporary Economic Policy, 23(3), 357-375.

Colorado Department of Public Health and Environment (2005). The Colorado Brownfields Handbook: A Local Government Guide to Site Reuse and Economic Redevelopment.

Conway, D, QC Li, J Wolch, C Kahle and M Jerrett (2010). Spatial autocorrelation approach for examining the effects of urban greenspace on residential property values. Journal of Real Estate Finance and Economics, 41, 150-169.

Corona, J (2004). Essays in brownfield redevelopment. Doctoral dissertation, University of Connecticut.

De Sousa, CA, C Wu and LM Westphal (2009). Assessing the effect of publicly assisted brownfield redevelopment on surrounding property values. Economic Development Quarterly, 23(2), 95-100. 
Gamper-Rabindran, S and C Timmins (2013). Does cleanup of hazardous waste sites raise housing values? Evidence of spatially localised benefits. Journal of Environmental Economics and Management, 65, 345-360.

Geoghegan, S, L Lynch and S Bucholtz (2003). Capitalisation of open spaces into housing values and the residential property tax revenue impacts of agricultural easement programs. Agricultural and Resource Economics Review, 32(1), 33-45.

Greenstone, M and T Gayer (2007). Quasi-experimental and experimental approaches to environmental economics. Resources for the Future Discussion Paper, RFF DP $07-22$.

Greenstone, M and J Gallagher (2008). Does hazardous waste matter? Evidence from the housing market and the superfund program. The Quarterly Journal of Economics, 123, 951-1003.

Haninger, K, L Ma and C Timmins (2017). The value of brownfield remediation. Journal of the Association of Environmental and Resource Economists, 4(1), 197-241.

Harris, B and BD Moore (2013). Residential property taxes in the United States. Paper from the Urban-Brookings Tax Policy Center.

Harris County Appraisal District, Texas (2015). Capped Values - Limitations on Increasing Property Values on Your Home. Available online: http://hcad.org/hcadresources/hcad-residential-property/hcad-capped-appraisal-values/09.

Ihlanfeldt, KR and LO Taylor (2004). Externality effects of small-scale hazardous waste sites: Evidence from urban commercial property markets. Journal of Environmental Economics and Management, 47(1), 117-139.

Jenkins, R, E Kopits and D Simpson (2006). Measuring the social benefits of EPA land cleanup and reuse programs. National Center for Environmental Economics, Working Paper No. 06-03.

Kaufman, DA and NR Cloutier (2006). The impact of small brownfields and greenspaces on residential property values. Journal of Real Estate and Financial Economics, 33, 19-30.

Kiel, K (1995). Measuring the impact of the discovery and cleaning of identified hazardous waste sites on house values. Land Economics, 71(3), 428-435.

Kiel, K and M Williams (2007). The impact of superfund sites on local property values: Are all sites the same? Journal of Urban Economics, 61, 170-192.

King, J and C Anderson (2004). Marginal tax effects of conservation easements: A vermont case study. American Journal of Agricultural Economics, 86(4), 919-932.

Michaels, R and VK Smith (1990). Market segmentation and valuing amenities with hedonic models: The case of hazardous waste sites. Journal of Urban Economics, 28(2), 223-242.

Mihaescu, O and R Vom Hofe (2012). The impact of brownfields on residential property values in Cincinnati, Ohio: A spatial hedonic approach. The Journal of Regional Analysis \& Policy, 42(3), 223-236. 
Mihaescu, O and R Vom Hofe (2013). Using spatial regression to estimate property tax discounts from proximity to brownfields: A tool for local policy-making. Journal of Environmental Assessment Policy and Management, 15(1), 23.

Palmquist, RB (2005). Property value models. In Handbook of Environmental Economics, Vol. 2, eds. K Goran-Maler and JR Vincent. Netherlands: Elsevier B.V., pp. 763-819.

Paull, E (2008). The environmental and economic impacts of brownfields redevelopment. Northeast Midwest Institute, Working Paper, Washington, DC.

Redevelopment Economics (2015). The federal brownfields tax incentive case studies and analysis of impacts. Report prepared for: New York City Mayor's Office of Environmental Remediation, International Council of Shopping Centers in Cooperation with Smart Growth America/National Brownfields Coalition. September 2015. Available online: http://www.redevelopmenteconomics.com/yahoo_site_adminassets/docs/fed_ brfds_taxincentive_section_198_case-study_analysis_final.25070108.pdf.

Rosen, S (1974). Hedonic prices and implicit markets: Product differentiation in pure competition. Journal of Political Economy, 82(1), 34-55.

Schwarz, PM, GL Gill, A Hanning and CA Cox (2016). Estimating the effects of brownfields and brownfield remediation on property values in a new south city. Contemporary Economic Policy, 35(1), 143-164.

Taylor, LO (2003). The Hedonic Method. In A Primer on Non-market Valuation of the Environment, T Brown, P Champ and K Boyle (eds.), Dordrecht: Kluwer Academic Publishers, pp. 331-393.

US Census Bureau (2000). Census 2000 Summary File 1 (SF1) 100-Percent Data, DP-1Profile of General Demographic Characteristics.

US Conference of Mayors (2010). Recycling America's land: A national report on brownfields redevelopment.

US Environmental Protection Agency (2011). Handbook on the Benefits, Costs and Impacts of Land Cleanup and Reuse. EPA-240-R-11-001.

US Environmental Protection Agency (2017). Overview of the Brownfields Program. Available online: https://www.epa.gov/brownfields/overview-brownfields-program.

Vandegrift, D and M Lahr (2011). Open space, house prices, and the tax base. The Annals of Regional Science, 46, 83-100.

Washoe County Assessor (2013). Tax cap information. Available online: http://www. washoecounty.us/assessor/taxcap.htm. [Retrieved 6 December 2013].

Wernstedt, K (2010). Gauging the outcomes of US brownfields revitalisation: A review of the impacts. Journal of Urban Regeneration and Renewal, 3, 216-232.

Wolverton, A (2009). Effects of socio-economic and input-related factors on polluting plants' locations decisions. BE Journal of Economic Analysis and Policy, 9(1), 1935-1982.

Yu, T, S Cho and SG Kim (2012). Assessing the residential property tax revenue impact of a shopping centre. Journal of Real Estate Finance and Economics, (45), 604-621. 